\title{
Transformation of sunflower oil production in Ukraine due to acute economic crisis
}

\author{
Roman Zavorotniy \\ Kyiv National Economic University named after Vadym Hetman \\ Ukraine \\ zavorotniy@freenet.de \\ Oleksandr Bilyk \\ Kyiv National Economic University named after Vadym Hetman \\ Ukraine \\ documents@kneu.edu.ua
}

\begin{abstract}
The article is dedicated to the assessment of influence of the acute postrevolutionary economic crisis on the development of oil-bearing crops production and sunflower oil extracting (as the most profitable segment of Ukrainian agricultural complex today). One of the most urgent problems is assessment of internal potential of economic reorientation and further development. The authors suggest estimating such changes through the analysis of macroeconomic indicators, analysis of the dynamics of financial state of the largest market participants (using a discriminant mod-el) and identification of the most influential drivers of the related corporate financial state. The last operation needs to include factor analysis and assessment of deviations in the discriminant results.
\end{abstract}

Keywords: discriminant model, a financial state of the enterprise, Total Support Estimate, factor analysis, method of chain substitutions.

JEL Classification: C33, G01, G23

\section{INTRODUCTION}

Such factors as reorganization of national political system, Russian military aggression (Andriychuk, 2013) with simultaneous annexation of a part of the state territories and depredation of Ukrainian enterprises' property, Russian economic blockade of the rest of them - all these factors forced Ukrainian economy rapidly reorient onto new world markets. At the same time the agrarian sector became the leader (by the export income volumes): in 2015 the share of food and agricultural products in the cumulative export 
was the largest reaching 38,2\%. The Agreement on Association with the European Union (2014) helped it and provided some duty-free preferences to Ukrainian export of agricultural goods and food, according to the approved quotas (in 2014 the duty-free export reached 83,4\% of all product groups). Also zero tariff duty charge was established on the majority of other products that were out of these quotas.

Unfortunately, such market liberalization hasn't accelerated much the development of Ukrainian agrarian enterprises and hasn't reduced the number of all new corporate bankruptcies. Identification of conditions hindering the development of the agrarian sector thus becomes more urgent and is the novelty of the research offered here.

\section{ANALYSIS OF CURRENT RESEARCHES}

Complex researches of problems of development of agricultural production (in particular, the sunflower cultivation) are presented in works (Andriychuk, 2013; Kucherenko, 2015; Fedoryaka, 2013; Verkhovod, 2014). However, professional publications aren't focused on comparison of development of the sector in the pre-revolutionary and post-revolutionary (2014 and further) period; they don't define the factors that maintain the production expansion.

The main purpose of presented work is a research of development of the most sustainable Ukrainian enterprises (in particular, the sunflower oil production as one of the most profitable business) in a prerevolutionary and post-revolutionary period. So, the object of article is economic activity of sunflower oil extracting enterprises. The main methods of research are the most-used methods of statistical analysis, in particular horizontal and vertical analysis and a factor analysis (i.e., a method of chain substitutions).

Results allow us to emphasize the most important financial factors of corporate development and to use them as the convenient tools in financial management.

\section{RESULTS}

Sustainable increase in production and export of sunflower oil allows Ukraine to keep leadership in the rating of the states-manufacturers and exporters of such production. More than a quarter of global amount of sunflower is produced in the country, and there more than $60 \%$ of world export of sunflower oil is carried out. It's caused by the highest profitability of oil-bearing crops production comparing to other profitable agrarian economic sectors (Table 1). However, sunflower oil production business of agrarian holdings is often separated from production of oil-bearing crops. That's why it is defined by rather lower profitability.

More than two thirds of production and the export potential in Ukraine are concentrated among eight market participants (Code of a Type of Economic Activity 10.41 "Sunflower Oil and Animal Fats Production"), that is shown in Table 2.

Table 2 and "Information on persons who own more than ten percent shares of the issuer" show that the majority of the sunflower oil producers in Ukraine are controlled by international economic structures. Therefore, high profitability of such Ukrainian business and its managing by the international investors provide the enterprises with the simplified access to the global capital market and considerably expands a spectrum of instruments of financial management. The moratorium on sale of land with an agricultural purpose forced the Ukrainian enterprises to attract the capital through crediting, IPO and SPO on the international stock exchanges for further acquisition of other agrarian firms with their own land bank. Since 2014 these processes stopped because of economic uncertainty. 
Table 1

The most profitable agrarian production in Ukraine in 2006-2015, \% (SSSU, 2016; Samaeva, 2016)

\begin{tabular}{|l|l|c|c|c|c|c|c|c|c|c|c|}
\hline \multirow{2}{*}{ No } & \multicolumn{1}{|c|}{ Production } & \multicolumn{10}{c|}{ Years } \\
\cline { 3 - 13 } & & $\mathbf{2 0 0 6}$ & $\mathbf{2 0 0 7}$ & $\mathbf{2 0 0 8}$ & $\mathbf{2 0 0 9}$ & $\mathbf{2 0 1 0}$ & $\mathbf{2 0 1 1}$ & $\mathbf{2 0 1 2}$ & $\mathbf{2 0 1 3}$ & $\mathbf{2 0 1 4}$ & $\mathbf{2 0 1 5}$ \\
\hline 1 & \multicolumn{1}{|c}{2} & 3 & 4 & 5 & 6 & 7 & 8 & 9 & 10 & 11 & 12 \\
\hline 1 & Products of plant growing & 11,3 & 32,7 & 19,6 & 16,9 & 26,7 & 32,3 & 22,3 & 11,1 & 29,2 & 50,9 \\
\hline 2 & Grain and leguminous crops & 7,4 & 28,7 & 16,4 & 7,3 & 13,9 & 26,1 & 15,2 & 1,5 & 25,8 & 43,2 \\
\hline 3 & Oil-bearing crops that include the: \\
\hline 3.1 & sunflower seeds & 20,7 & 75,9 & 18,4 & 41,4 & 64,7 & 57 & 45,8 & 28,5 & 36,5 & 80,3 \\
\hline 3.2 & soy & $\mathrm{n} / \mathrm{d}$ & $\mathrm{n} / \mathrm{d}$ & $\mathrm{n} / \mathrm{d}$ & $\mathrm{n} / \mathrm{d}$ & $\mathrm{n} / \mathrm{d}$ & $\mathrm{n} / \mathrm{d}$ & $\mathrm{n} / \mathrm{d}$ & $\mathrm{n} / \mathrm{d}$ & 34,5 & 38,4 \\
\hline 3.2 & colza & $\mathrm{n} / \mathrm{d}$ & $\mathrm{n} / \mathrm{d}$ & $\mathrm{n} / \mathrm{d}$ & $\mathrm{n} / \mathrm{d}$ & $\mathrm{n} / \mathrm{d}$ & $\mathrm{n} / \mathrm{d}$ & $\mathrm{n} / \mathrm{d}$ & $\mathrm{n} / \mathrm{d}$ & 29,2 & 44,0 \\
\hline 4 & Outdoor cropping & 14,8 & 14,1 & 11,1 & 19,1 & 23,5 & 9,9 & $-6,8$ & 7 & 16,7 & 47,6 \\
\hline 5 & Chicken eggs & $-6,8$ & 9,1 & 13 & 13,1 & 18,6 & 38,8 & 52,6 & 47,6 & 58,8 & 61,4 \\
\hline
\end{tabular}

Table 2

Concentration of production in Ukrainian sunflower oil production in the beginning of 2016

\begin{tabular}{|c|c|c|c|c|}
\hline № & $\begin{array}{c}\text { Market } \\
\text { participants }\end{array}$ & $\begin{array}{c}\text { Weight in a } \\
\text { whole } \\
\text { production, } \\
\%\end{array}$ & $\begin{array}{c}\text { Oil production firms as parts of the total assets of every } \\
\text { participant }\end{array}$ & $\begin{array}{l}\text { Geographic } \\
\text { position }\end{array}$ \\
\hline 1 & 2 & 3 & 4 & 5 \\
\hline \multirow{6}{*}{1} & \multirow{6}{*}{ Kernel Group } & \multirow{6}{*}{26,1} & $\begin{array}{c}\text { CJSC "Prukolotnyanskiy Oil Processing Plant" (Unified State } \\
\text { Register of the Enterprises and Organizations of Ukraine, } \\
\text { USREOU no. 00373913) }\end{array}$ & Kharkiv region \\
\hline & & & $\begin{array}{c}\text { CJSC "Vovchanskiy Oil Processing Plant" } \\
\text { (USREOU no. 00373936) }\end{array}$ & Kharkiv region \\
\hline & & & $\begin{array}{c}\text { CJSC "Poltavskiy Oil Processing Plant - Kernel Group" } \\
\text { (USREOU no. 00373907) }\end{array}$ & Poltava region \\
\hline & & & PJSC “Kirovogradoliya” (USREOU no. 00373869) & Kirovograd region \\
\hline & & & $\begin{array}{c}\text { "Bandurivskiy Oil Processing Plant Ltd." } \\
\text { (USREOUno. 32390305) }\end{array}$ & Mykolayv region \\
\hline & & & $\begin{array}{l}\text { "Ukrainska Chornomorska Industruya Ltd." } \\
\text { (USREOUno. 32790454) }\end{array}$ & Odessa region \\
\hline 2 & $\begin{array}{l}\text { Industrial Group } \\
\text { "Creative" }\end{array}$ & 10,3 & PJSC “Creative” (USREOU no. 31146251) & Kirovograd region \\
\hline \multirow{3}{*}{3} & \multirow{3}{*}{ Cargill Group } & \multirow{3}{*}{8,3} & $\begin{array}{l}\text { "Cargill-Kakhovka Oil Processing Plant Ltd." } \\
\text { (USREOUno. 20010397) }\end{array}$ & Kherson region \\
\hline & & & $\begin{array}{l}\text { «Cargill Industrial Complex Ltd.» } \\
\text { (USREOU no. 25606399) }\end{array}$ & Donetsk region \\
\hline & & & $\begin{array}{l}\text { PJSC "Chernivetskiy Oil Processing Plant" } \\
\text { (USREOUno. 00373959) }\end{array}$ & Chernivtsi region \\
\hline 4 & Agrokosm Group & 8,1 & $\begin{array}{c}\text { PJSC “Zaporizkiy oliyazhyrkombinat” } \\
\text { (USREOUno. 00373847) }\end{array}$ & Zaporizhya region \\
\hline 5 & $\begin{array}{l}\text { Mironivsky } \\
\text { Hliboproduct } \\
\text { Group } \\
\end{array}$ & 7,1 & $\begin{array}{c}\text { PJSC «Mironivsky plant on production of grain and compound } \\
\text { feeds» (USREOU no. 00951770) }\end{array}$ & Kyiv region \\
\hline 6 & Vioil Group & 7 & $\begin{array}{c}\text { PJSC «Vinnitskiy Oliynozhiroviy Kombinat» } \\
\text { (USREOUno. 00373758) }\end{array}$ & Vinnitsa region \\
\hline 7 & Bunge Group & 4,9 & $\begin{array}{c}\text { CJSC «Dnipropetrovskiy Oil Processing Plant» } \\
\text { (USREOU no. 00374385) }\end{array}$ & $\begin{array}{l}\text { Dnipropetrovsk } \\
\text { region }\end{array}$ \\
\hline 8 & Von Sass AG & 4 & $\begin{array}{l}\text { PJSC «Pologivskiy Oil Processing Plant» } \\
\text { (USREOU no. 00384147) }\end{array}$ & Zaporizhya region \\
\hline
\end{tabular}

Source: made by authors on a basis of (Infographic Reference Book, 2015, 38) 
So, ensuring oil-bearing crops production and processing was a regular purpose for attraction of the capital by these enterprises during the last ten years. Table 3 shows high efficiency of such policy in both directions as ensuring intensive and extensive economic development.

Almost all amount of the seeds (except the sowing fund) loads domestic processing capacities because of a custom barrier for raw materials export.

Table 3

The development of Ukrainian oil-bearing crops sector in 2002-2015

\begin{tabular}{|c|c|c|c|c|c|c|c|c|c|c|}
\hline \multirow{2}{*}{ Years } & \multicolumn{4}{|c|}{ Cultivated area, ths hectares } & \multicolumn{3}{c|}{ Total gathering, ths tonnes } & \multicolumn{2}{|c|}{ Productivity, cwt/hectare } \\
\cline { 2 - 12 } & sunflower & colza & soy & $\begin{array}{c}\text { oil- } \\
\text { bearing } \\
\text { crops, } \\
\text { total }\end{array}$ & sunflower & colza & soy & sunflower & colza & soy \\
\hline 1 & 2 & 3 & 4 & 5 & 6 & 7 & 8 & 9 & 10 & 11 \\
\hline 2006 & 3912 & 386,8 & 714,82 & 5013,62 & 5324 & 605,7 & 889,6 & 13,61 & 15,66 & 12,45 \\
\hline 2007 & 3411,4 & 802,7 & 583 & 4797,1 & 4173,6 & 1058 & 722 & 12,23 & 13,18 & 12,38 \\
\hline 2008 & 4279,5 & 1379,6 & 537,9 & 6197 & 6526,2 & 2872,8 & 812,8 & 15,25 & 20,82 & 15,11 \\
\hline 2009 & 4192,8 & 1013,7 & 622,5 & 5829 & 6360,6 & 1873,3 & 1042,5 & 15,17 & 18,48 & 16,75 \\
\hline 2010 & 4525,8 & 862,5 & 1036,6 & 6424,9 & 6769,4 & 1469,7 & 1680,2 & 14,96 & 17,04 & 16,21 \\
\hline 2011 & 4716,2 & 832,8 & 1110,3 & 6659,3 & 8800 & 1437,5 & 2264,4 & 18,66 & 17,26 & 20,39 \\
\hline 2012 & 5080,9 & 547 & 1412,4 & 7040,3 & 8387,1 & 1204,4 & 2410,2 & 16,51 & 22,02 & 17,06 \\
\hline 2013 & 5089,4 & 996,1 & 1350,7 & 7436,2 & 10600 & 2353 & 2762,5 & 20,83 & 23,62 & 20,45 \\
\hline 2014 & 5200 & 996 & 1500 & 7696 & 10100 & 2199 & 3869,833 & 19,42 & 22,08 & 25,8 \\
\hline 2015 & 5000 & 881 & 1803 & 7684 & 10300 & 2295 & 4400 & 20,6 & 26,05 & 24,4 \\
\hline
\end{tabular}

Source: made by authors on a basis of (SSSU, 2016)

Fig. 1 shows influence of the annual dynamics of oil-bearing crops production (that is in Table 3) on the amount of export.

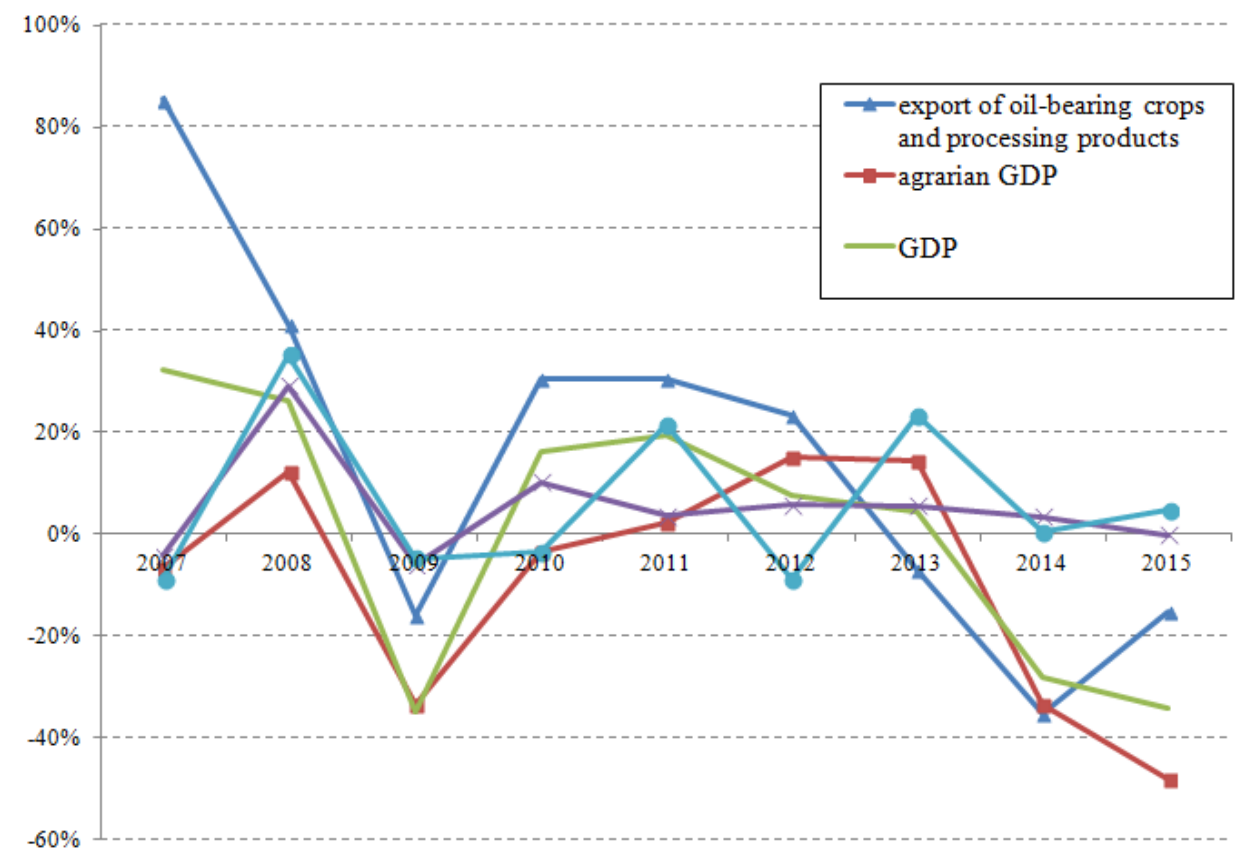

Figure 1. Annual dynamics of cultivated area under oil-bearing crops, export and GDP, 2007-2015 
Fig. 1 clearly shows correlation among the majority of presented economic indicators. Let's place in Table 4 the ratios of such correlation to formalize interrelation between the presented indicators and to define influence of economical and political changes in the country.

Table 4

Correlation between dynamics of cultivated area under oil-bearing crops, the corresponding export and

GDP in 2007-2015

\begin{tabular}{|c|c|c|c|c|c|c|}
\hline \multirow{2}{*}{ Years } & \multicolumn{6}{|c|}{ Correlation of dynamics of indicators } \\
\cline { 2 - 7 } & $\begin{array}{c}\text { cultivated } \\
\text { area and } \\
\text { export }\end{array}$ & $\begin{array}{c}\text { cultivated } \\
\text { area and } \\
\text { agrarian GDP }\end{array}$ & $\begin{array}{c}\text { cultivated } \\
\text { area and } \\
\text { GDP }\end{array}$ & $\begin{array}{c}\text { export and } \\
\text { agrarian GDP }\end{array}$ & $\begin{array}{c}\text { agrarian } \\
\text { GDP and } \\
\text { GDP }\end{array}$ & $\begin{array}{c}\text { export } \\
\text { and GDP }\end{array}$ \\
\hline $2007-2013$ & 0,11 & 0,6 & 0,44 & 0,2 & 0,63 & 0,84 \\
\hline $2007-2015$ & 0,2 & 0,54 & 0,46 & 0,55 & 0,82 & 0,89 \\
\hline
\end{tabular}

As is shown in Table 4, lack of correlation between dynamics of an extensive development of the oilbearing crops cultivation and dynamics of such export emphasizes the insignificance of increasing in cultivated areas as economic factor. It was caused by intensive methods of increasing in productivity (as Table 3 shows, productivity of some species of oil-bearing crops increased twice for 10 years). The great weight of oil-bearing crops production in total structure of agrarian GDP caused increase in an indicator of mutual correlation to 0,54 . Decrease in this indicator comparing to indicators of the pre-war period particularly is caused by loss in huge cultivated areas of some parts of Donetsk and Lugansk regions, Crimea, and 7 local sunflower oil production plants.

Increase in correlation between dynamics of agrarian GDP and total GDP in period after the beginning of Russian military invasion (from 0,63 in 2006-2013 to 0,82 in 2006-2015) tells us about restructuring of national GDP through increasing of weight of agricultural sector. Generally it is caused by destruction of industrial potential in the East of Ukraine. Such factors caused increase in ratios of correlation between dynamics of export of oil-bearing crops, agrarian GDP, and also of total GDP dynamics (for the first pair: 0,2 in 2006-2013, 0,55 in 2006-2015; for export and GDP: 0,84 in 2006-2013, 0,89 in 2006-2015).

The assessment of influence by intensive development of oil-bearing crops cultivation on some macroeconomic data has revealed lack of any correlation. It can be explained by rather low introduction of innovations (for instance, Ukrainian sunflower production had reached 20,6 cwt/hectare in 2015 and was lower than the productivity of popular European crops PR64F50 and PR64A15 with their 40-50 cwt/hectare).

Investments in growing of production base and increasing of productivity in Ukrainian agrarian sector have two main sources: state financing (subsidies for purchase of the production assets, privileges and the credits with the pledge of seeds) and private corporate investments.

Destructive influence of the state support on the example of Total Support Estimate (that was found by Organization for Economic Cooperation and Development) is in Table 5.

According to Table 5, the support of agrarian producers gradually reduced in a whole analyzed period. Decrease in TSE and PSE indicators in EU countries has reached 29,3\% and 35\%, at the same time in the conditions of an acute financial crisis such reduction in Ukraine has reached 213,8\% and 164,2\%. It indicates reduction in the state support of agrarian sector to the scanty size. 
Table 5

Dynamics of the state financial support of the agrarian sector in Ukraine and EU in 2006-2015, mln. euro

(OECD, 2016)

\begin{tabular}{|c|c|c|c|c|c|c|c|c|}
\hline \multirow{2}{*}{$\begin{array}{c}\text { Year } \\
\text { s }\end{array}$} & \multicolumn{4}{|c|}{ TSE } & \multicolumn{3}{c|}{ Producer Subsidy Equivalent,PSE } \\
\cline { 2 - 9 } & $\mathbf{n}$ & Ukraine & \multicolumn{2}{|c|}{ European Union } & \multicolumn{2}{c|}{ Ukraine } & \multicolumn{2}{c|}{ European Union } \\
\hline 1 & 2 & 3 & 4 & 5 & 6 & 7 & 8 & \multicolumn{2}{c|}{$\begin{array}{c}\text { Part in } \\
\text { GDP, } \%\end{array}$} & Amount & $\begin{array}{c}\text { Part in GDP, } \\
\text { \% }\end{array}$ \\
\hline 2006 & 2298,16 & 2,68 & 115222,9 & 0,99 & 1892,4 & 10,9 & 99098,3 & 29,06 \\
\hline 2007 & 1087,23 & 1,04 & 106886,3 & 0,86 & 600,4 & 3,07 & 90518,6 & 23,35 \\
\hline 2008 & 1018,07 & 0,83 & 113473,1 & 0,91 & 529,4 & 2,24 & 94909,6 & 23,13 \\
\hline 2009 & 1615,23 & 1,91 & 101751,9 & 0,86 & 1265,6 & 7,33 & 86818,8 & 23,6 \\
\hline 2010 & 1999,66 & 1,94 & 94858,27 & 0,77 & 1536,6 & 6,49 & 79550,6 & 20,28 \\
\hline 2011 & $-50,02$ & $-0,04$ & 93990,65 & 0,74 & -536 & $-1,91$ & 78620,5 & 18,35 \\
\hline 2012 & 1038,2 & 0,76 & 98688,71 & 0,76 & 435,4 & 1,5 & 83837,6 & 19,13 \\
\hline 2013 & $-556,43$ & $-0,41$ & 106434,1 & 0,82 & $-1051,5$ & $-3,18$ & 91375,9 & 20,47 \\
\hline 2014 & $-1939,57$ & $-2,23$ & 94235,38 & 0,71 & $-2159,1$ & $-8,22$ & 80003 & 18,36 \\
\hline 2015 & no data & $-3,05$ & no data & 0,7 & no data & -7 & no data & 18,9 \\
\hline
\end{tabular}

TSE and PSE indicators became the negative values since the beginning of political and economic crisis (2013). Generally it occurred due to payments of the single tax on the cultivated areas and the stop subsidizing. In particular, agrarian producers have got considerable losses owing to the termination of public procurements to Agrarian fund, for the purpose of market prices regulation. Simultaneously, price risks of the sunflower oil and fats industry are scanty, because there was a deficiency of sunflower seeds in the Ukrainian market during all the analyzed period; it has caused steady underutilization of processing capacities and rather high cost of raw materials. For instance, in October, 2016 the price was up to 335 euro/t (including tax on additional cost, on condition of EXW), whereas its price in Poland was at 320 euro/t. So, critical state of economy caused negative measure values of the state financial support of crop production and significantly slowed down its development in the medium-term perspective.

As well as the described reduction in the state financing, financial crisis also caused impossibility of investment through financing by the domestic private sector. Therefore, direct foreign investment (DFI) carries out the main role in financial ensuring of development of national agrarian sector. Its dynamics is shown in Fig. 2.

The growing of DFI in agrarian sector was sustainable until the political crisis of 2014. Dynamics of total investments was considerably reduced since the beginning of crisis of 2008. Nevertheless, the annual amount of DFI into agriculture was characterized by high correlation with a total DFI in all period (with 0,83), and the maximum level of agrarian DFI ever was not higher than 1,9\% of a total DFI. Restoration of investment in flow was observed from 1sthalf of 2015 (when its total amount had risen to 3,6\% of GDP)because of recapitalization of the international banks. Last factor intensified financing of agriculture as the most creditworthy sector of national economy. 


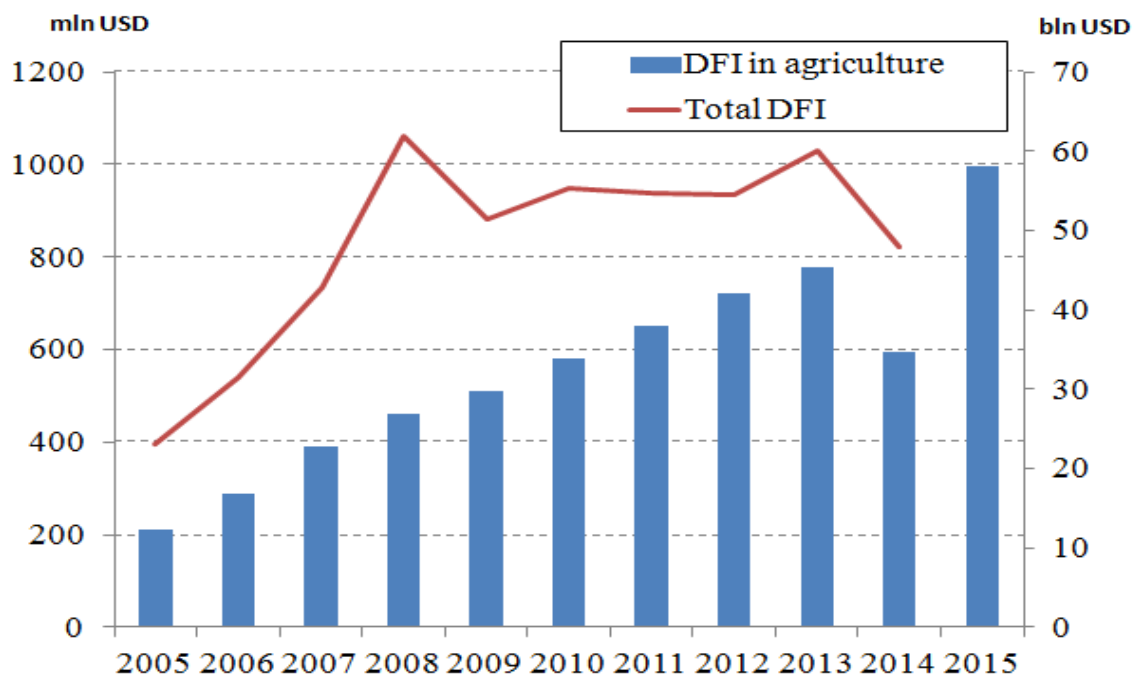

Figure 2. Dynamics of DFI in Ukraine for the 2005-2015 (OECD, 2015, 25)

In a whole, influence of all economic conditions on financial state of any enterprise can be estimated by use of some discriminant models. E.g., the model by Tereschenko O. that is adapted for the researched enterprises is in Order by Ministry of Finance of Ukraine (No. 616, 14.07.2016) and has the following form:

$$
Z=1,3 * k_{3}+0,03 * k_{4}+0,001 * k_{5}+0,61 * k_{6}+0,75 * k_{7}+2,5 * k_{8}+0,04 * k_{9}-0,2,
$$

( $\mathrm{k}_{3}$ is a financial independence ratio, $\mathrm{k}_{4}$ means a coefficient of a covering of non-current assets with equity, $\mathrm{k}_{5}$ means a coefficient of an equity profitability, $\mathrm{k}_{6}$ is a ratio of sales profitability through EBIT, $\mathrm{k}_{7}$ is a coefficient of sales profitability through EBITDA, $\mathrm{k}_{8}$ is a ratio of net assets profitability, $\mathrm{k}_{9}$ is current assets turnover ratio).

The technique of creation of such discriminant model is similar to Beerman Discriminant Function and Altman Z-Score (obviously, there are other approaches as artificial neural networks (Mihalovič, 2016, 103), but they are more complicated). All kinds of the model by Tereschenko O. (for various kinds of economic activity in Ukraine) are in Order presented (No. 616, 14.07.2016). In particular, Order contains the frontiers that relate to every type of enterprise's financial state. The model for agricultural enterprises has the next frontiers:

- $\quad$ Z > 0,5, class I: a sustainable financial state, little possibility of bankruptcy;

- $\quad-0,1<Z<0,49$, class II: a financial state is sufficient, some little credibility of bankruptcy;

- $\quad-0,11<Z<-0,75$, class III: enterprise's solvency is insufficient;

- $\quad-0,76<Z<-4,2$, class IV: a financial state is critical, many signs of insolvency;

- $\quad Z<-4,2$, class V: high possibility of corporate default.

Resulting Z-indicators of a financial state of the enterprises and classes that fit to them (in 2011-2015) are provided in Table 6.

Table 6 characterizes some invariance of a financial state of the majority of such enterprises (in comparison with the first year, 2011). Intervals with the significant change of $\mathrm{Z}$-indicator values and the financial state classes are noted by italics in Table 6 (according to model, probability of corporate bankruptcy). 
Table 6

Discriminant Z-indicators of a financial state of the enterprises in 2011-2015

\begin{tabular}{|c|c|c|c|c|c|c|}
\hline \multirow{2}{*}{ № } & \multirow{2}{*}{ Enterprise } & \multicolumn{5}{|c|}{ Years } \\
\hline & & 2011 & 2012 & 2013 & 2014 & 2015 \\
\hline 1 & 2 & 3 & 4 & 5 & 6 & 7 \\
\hline 1.1 & CJSC "Vovchanskiy Oil Processing Plant" & 1,65 & 1,827 & $-3,513$ & 2,369 & 1,599 \\
\hline 1.2 & Type of a financial state & $\mathrm{I}$ & $I$ & $V$ & $I$ & I \\
\hline 2.1 & PJSC "Creative" & 0,295 & 0,11 & 0,269 & $-3,432$ & $-55,485$ \\
\hline 2.2 & Type of a financial state & II & II & II & $I V$ & $V$ \\
\hline 3.1 & PJSC “Zaporizkiy oliyazhyrkombinat" & 0,246 & 0,268 & 0,283 & $-0,034$ & 0,453 \\
\hline 3.2 & Type of a financial state & II & II & II & III & II \\
\hline 4.1 & PJSC “Chernivetskiy Oil Processing Plant” & 1,332 & $-2,763$ & 1,33 & $-0,285$ & 1,927 \\
\hline 4.2 & Type of a financial state & I & IV & I & III & $\mathrm{I}$ \\
\hline 5.1 & $\begin{array}{l}\text { CJSC "Poltavskiy Oil Processing Plant - Kernel } \\
\text { Group" }\end{array}$ & 1,315 & 0,692 & 1,141 & 0,215 & $-0,55$ \\
\hline 5.2 & Type of a financial state & I & II & I & II & III \\
\hline 6.1 & PJSC «Vinnitskiy Oliynozhiroviy Kombinat» & 1,424 & 1,063 & 0,72 & 1,257 & 1,075 \\
\hline 6.2 & Type of a financial state & I & I & I & I & $\mathrm{I}$ \\
\hline 7.1 & $\begin{array}{l}\text { PJSC «Mironivsky plant on production of grain } \\
\text { and compound feeds» }\end{array}$ & $-0,546$ & $-0,57$ & $-0,594$ & $-0,76$ & $-0,689$ \\
\hline 7.2 & Type of a financial state & III & III & III & IV & III \\
\hline 8.1 & PJSC "Kirovogradoliya" & 1,867 & 1,994 & 2,011 & 1,764 & 2,248 \\
\hline 8.2 & Type of a financial state & I & I & I & I & $\mathrm{I}$ \\
\hline 9.1 & CJSC «Dnipropetrovskiy Oil Processing Plant» & 1,98 & 1,99 & 2,3 & 2,012 & 1,755 \\
\hline 9.2 & Type of a financial state & I & I & $\mathrm{I}$ & I & I \\
\hline $\begin{array}{c}10 . \\
1\end{array}$ & PJSC «Pologivskiy Oil Processing Plant» & 0,238 & 1,876 & 0,307 & 0,278 & 0,562 \\
\hline $\begin{array}{c}10 . \\
2\end{array}$ & Type of a financial state & II & $\mathrm{I}$ & II & II & II \\
\hline
\end{tabular}

Next step, we need to define common rules or main drivers of considerable changes in a financial state of such enterprises that are emphasized in Table 6. For this purpose we have defined influence of each of elements of discriminant model on dynamics of annual Z-coefficient values by use a method of chain substitutions. The analysis technique has the following algorithm (based on financial performance of CJSC "Vovchanskiy Oil Processing Plant" in 2012-2013):

$$
\text { 1) } \begin{aligned}
Z_{2012}=0,0035 * k_{12} 2012 & +0,04 * k_{22} 2012+2,7 * k_{32} 2012+0,1 * k_{62012}+1,1 * k_{7} 2012 \\
& +0,05 * k_{092012}-0,8=1,827275 ;
\end{aligned}
$$

2) influence ofk $k_{1}$ change on annual $Z$ dynamics:

3)

$$
\begin{aligned}
& \left(0,0035 * k_{12} 2013+0,04 * k_{2} 2012+2,7 * k_{3} 2012+0,1 * k_{6} 2012+1,1 * k_{7} 2012+1,2 * k_{8} 2012+0,05 * k_{0} 2012-\right. \\
& -0,8)-\left(0,0035 * k_{12012}+0,04 * k_{22} 2012+2,7 * k_{32012}+0,1 * k_{6} 2012+1,1 * k_{72012}+1,2 * k_{8} 2012+\right.
\end{aligned}
$$




$$
\left.+0,05 * k_{9} 2012-0,8\right)=1,827653-1,827275=-0,0004 \text {. }
$$

Influence of each other indicator on change of result of discriminant model value is defined by a similar way (through gradual updating of each other k-ratio value in the model formula). Extent of influence of each k-ratio in structure of discriminant model is calculated concerning on a whole interval of fluctuations of Z-indicator. For instance, we offer the following formula to define the kinfluence on change of Zindicator of CJSC "Vovchanskiy Oil Processing Plant" financial state (in 2012):

$$
\begin{gathered}
\frac{\mid \text { Influence of } k_{1} \text { on change of } Z \text { value } \mid}{\sum_{i=1}^{n} \mid \text { Influence of all } k-\text { ratios on change of } Z \text { value } \mid} * 100 \%= \\
=\frac{|0,000378|}{|-0,0004|+|0,0783|+|0,0004|+|-0,0066|+|-5,3352|+|-0,07745|} * 100 \%=0,01 \% \text {. }
\end{gathered}
$$

Indicators that were defined through such method are in Table 7.

\begin{tabular}{|c|c|c|c|c|c|c|c|c|c|c|c|c|c|c|c|c|c|}
\hline Enterprises & Years & $\mathrm{k}_{1}$ & $\mathrm{k}_{2}$ & $\mathrm{k}_{3}$ & $\mathrm{k}_{6}$ & $\mathrm{k}_{7}$ & $\mathrm{k}_{8}$ & $\mathrm{k}_{9}$ & $\begin{array}{l}\text { Enterprise } \\
\mathrm{s}\end{array}$ & $\begin{array}{c}\text { Year } \\
\mathrm{s}\end{array}$ & $\mathbf{k}_{1}$ & $\mathrm{k}_{2}$ & $\mathrm{k}_{3}$ & $\mathrm{k}_{6}$ & $\mathrm{k}_{7}$ & $\mathrm{k}_{8}$ & $\mathrm{k}_{9}$ \\
\hline & & & 4 & 5 & & 1 & 8 & , & & & & & & & & & 18 \\
\hline \multirow{4}{*}{$\begin{array}{c}\text { CJSC } \\
\text { "Vovchanskiy } \\
\text { Oil } \\
\text { Processing } \\
\text { Plant" }\end{array}$} & & & & & & & & 45,8 & \multirow{4}{*}{$\begin{array}{c}\text { PJSC } \\
\text { «Vinnitskiy } \\
\text { OK» }\end{array}$} & & & & 72,0 & 0 & & 6 & 19,0 \\
\hline & 2013 & 0 & 0 & 1,4 & & 0,1 & & 1,5 & & 2013 & 0,3 & 0 & 79,3 & 0,6 & 6,5 & 2 & 3,1 \\
\hline & 2014 & 0,3 & 0 & 4,6 & 0 & 0 & 90,5 & 4,5 & & 2014 & 0,3 & 0 & 47,1 & 3,5 & 39,9 & & 8,9 \\
\hline & 2015 & 1,8 & 0 & 52,1 & 0,4 & 5,4 & 4,4 & 35,4 & & 2015 & & 0 & 20,4 & 2,4 & 1,9 & & 9,3 \\
\hline \multirow{4}{*}{$\begin{array}{c}\text { PJSC } \\
\text { "Creative" }\end{array}$} & 2012 & ני & 0,4 & 68,5 & 2 & 9,1 & 14,6 & 0,9 & \multirow{4}{*}{$\begin{array}{c}\text { PJSC } \\
\text { «Mironivsky } \\
\text { PP» }\end{array}$} & 2012 & 0,8 & 0,2 & 41,1 & 1,9 & 4,1 & 1,9 & 50,1 \\
\hline & 2013 & 0,1 & 0,2 & 59,0 & 2,9 & 22,8 & 2,6 & 12,4 & & 2013 & 1,4 & 0,4 & 60,7 & 1,5 & & & 15,4 \\
\hline & 2014 & 0,2 & 0,1 & 59,5 & 1,8 & 18,3 & 15,3 & 4,8 & & 2014 & & 0,1 & 46,2 & 4 & & & 10,1 \\
\hline & 2015 & 0 & 0 & 66,9 & $\overline{0,8}$ & 7,9 & 19,7 & 4,8 & & 2015 & 0,3 & 0,1 & 36,7 & 0,6 & 3 & 28 & 21,2 \\
\hline \multirow{4}{*}{$\begin{array}{c}\text { PJSC } \\
\text { “Zaporizkiy } \\
\text { oliyazhyrkom } \\
\text { binat" }\end{array}$} & 2012 & & 0 & 29,1 & 1,7 & 3,4 & 29,6 & 35,8 & \multirow{4}{*}{$\begin{array}{c}\text { PJSC } \\
\text { "Kirovograd } \\
\text { oliya" }\end{array}$} & 2012 & 8,4 & 0 & 42,2 & 1,6 & 27,2 & 7,9 & 12,7 \\
\hline & 2013 & 0,1 & 0 & 15,5 & 1,6 & 40,5 & 10,8 & 31,6 & & 2013 & 11,8 & 2,0 & 31,1 & 2,0 & 16,9 & , 0 & 21,3 \\
\hline & 2014 & 0 & 0 & 50,6 & 0,8 & 34,0 & 1,7 & 12,9 & & 2014 & 4,3 & 1,1 & 58,5 & 1,9 & 20,6 & 6,3 & 7,3 \\
\hline & 2015 & 0,1 & 0 & 43,9 & 2,1 & $1+, 0$ & 27,9 & 12,0 & & 2015 & 10,0 & 0,1 & 14,4 & 0,3 & 6,8 & & 2,0 \\
\hline \multirow{4}{*}{$\begin{array}{c}\text { PJSC } \\
\text { "Chernivetski } \\
\text { y Oil } \\
\text { Processing } \\
\text { Plant" }\end{array}$} & & 0 & 0 & 1,4 & & & 96,7 & 1,6 & \multirow{4}{*}{$\begin{array}{c}\text { CJSC } \\
\text { «Dnipropetro } \\
\text { vskiy OPP» }\end{array}$} & 2012 & & 0 & 31,2 & 3,2 & 18,8 & & 18,8 \\
\hline & 2013 & 0 & 0 & 1,9 & & 2,6 & 92,0 & 3,4 & & 2013 & 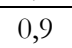 & 0,1 & 7,9 & 0,3 & 2,9 & & 82,6 \\
\hline & 2014 & 0,1 & 0 & 91,0 & 0,9 & 7,4 & 0,5 & 0,2 & & 2014 & 0,6 & 0 & 13,7 & 2,3 & 0,6 & 20 & 61,9 \\
\hline & 2015 & 0,1 & 0 & 93,5 & 0,3 & 4,1 & 0,3 & 1,8 & & 2015 & 0,6 & 0,1 & 1,1 & 5,2 & 34,0 & 51 & 7,4 \\
\hline \multirow{4}{*}{$\begin{array}{c}\text { CJSC } \\
\text { "Poltavskiy } \\
\text { OPP - Kernel } \\
\text { Group" }\end{array}$} & 2012 & & 0 & 41,2 & & 23,7 & 15,4 & 18,1 & \multirow{4}{*}{$\begin{array}{c}\text { PJSC } \\
\text { «Pologivskiy } \\
\text { OPP» }\end{array}$} & 2012 & 0 & 0,4 & 12,4 & 0 & 3,5 & 82 & 1,2 \\
\hline & 2013 & 4,5 & 0 & 64,9 & 0,2 & 10,5 & 1,9 & 18,0 & & 2013 & 0 & 0,1 & 14,7 & 0 & 0,4 & 83,5 & 1,3 \\
\hline & 2014 & 0,8 & 0 & 60,7 & 0,5 & 0,7 & 22,2 & 15,1 & & 2014 & 0,1 & 0 & 32,1 & 3,2 & 32,0 & 22,7 & 9,8 \\
\hline & 2015 & 1,6 & 0 & 78,0 & 0,5 & 8,9 & 4,2 & 6,8 & & 2015 & 0 & 0,1 & 39,0 & 1,6 & 18,2 & 33,4 & 7,8 \\
\hline
\end{tabular}

Table 7

Influence of dynamics of every ratio on annual values of discriminant model

In Table 7 certain cells were marked in the gray color, and they correspond to the most influential element of the financial state Z-model. In Table 8 we have to display statistics about such most influential coefficients in the pre-revolutionary and post-revolutionary periods, and also in a whole chronological interval. 
Table 8

The most influential coefficients of a financial state of the enterprises in each chronological interval

\begin{tabular}{|c|c|c|c|c|c|c|}
\hline \multirow{3}{*}{ Coefficients } & \multicolumn{7}{|c|}{ Weight in chronological interval } \\
\cline { 2 - 7 } & \multicolumn{2}{|c|}{$2012-2013$} & \multicolumn{2}{c|}{$\mathbf{2 0 1 4 - 2 0 1 5}$} & \multicolumn{2}{c|}{ 2012-2015 } \\
\cline { 2 - 7 } & Quantity & $\mathbf{\%}$ & Quantity & $\mathbf{\%}$ & Quantity & \% \\
\hline 1 & 2 & 3 & 4 & 5 & 6 & 7 \\
\hline $\mathrm{k}_{3}$ & 10 & 50 & 15 & 75 & 25 & 62,5 \\
\hline $\mathrm{k}_{7}$ & 1 & 5 & 1 & 5 & 2 & 5 \\
\hline $\mathrm{k}_{8}$ & 5 & 25 & 3 & 15 & 8 & 20 \\
\hline $\mathrm{k}_{9}$ & 4 & 20 & 1 & 5 & 5 & 12,5 \\
\hline
\end{tabular}

Table 8 shows influence of both cover coefficients (the main and intermediate, $\mathrm{k}_{1}$ and $\mathrm{k}_{2}$ ), and also of coefficients of sales profitability with EBIT and EBITDA $\left(\mathrm{k}_{6}\right.$ and $\left.\mathrm{k}_{7}\right)$ on dynamics of a financial state Zindicator in a whole analyzed period. So, all indicators of liquidity and sales profitability didn't significant influence on Z-coefficient dynamics, however influence of financial stability coefficient (financial independence, or autonomy, $\mathrm{k}_{3}$ ) was the most considerable in such dynamics, see Table 8.It is necessary to emphasize that during the post-revolutionary period influence of coefficient has grown by 1,5 times and it was huge at $75 \%$ of cases.

Net return on assets ratio $\left(\mathrm{k}_{8}\right)$ is the most influential among profitability indicators because a net profit is rather the main financial source of economic development than intermediate financial results (EBIT and EBITDA). Deficit of net profit forces the enterprise to attract the additional capital; such action directly changes financial state of every corporate structure.

The rather supporting role of $\mathrm{k}_{8}$ coefficient in influence on a financial state (among a whole set of $\mathrm{Z}$ model elements) of the analyzed enterprises is characterized by less relation between dynamics of a net profit and amount of an equity (as a basis of sustainable financial state). Decrease in a net profit not necessary changes a financial state of the enterprise (in such focus, relation between dynamics of an equity amount and a corporate default probability is much closer).

It is necessary to emphasize that the relation between dynamics of net return on assets and a financial state of the enterprises in post-revolutionary period was less expressed. The role of the current assets turnover ( $\mathrm{k}$, as an indicator of business activity) decreases in the same way, see Table 8.Increasing in relation between dynamics of financial independence ratio $\left(k_{3}\right)$ and a financial state of the enterprises can be explained through reduce in number of instruments of management by a financial state in the postrevolutionary market conditions. For this reason, such ratio also has taken the defining role. $\mathrm{k}_{3}$ indicator dynamics has taken the defining role at $90 \%$ of these enterprises in 2014, in the conditions of market shock and harsh market reorientation. However, the sustainable world demand on sunflower oil in 2015 allowed the Ukrainian oil-extracting plants to reduce such role, simultaneously doing some good to other financial levers $\left(\mathrm{k}_{7}\right.$ and $\mathrm{k}_{8}$, see Table 8 ). Of course, the analytical base is limited only to the two-year post-revolutionary period and will rise in the long term, but obviously the role and number of various financial levers will grow during the further enterprises expansion in the world markets. 


\section{CONCLUSIONS}

Thus, we have revealed concentration of $75 \%$ of the Ukrainian sunflower oil extracting at the eight enterprises. Sustainable market demand and high assets turnover cycle caused rather stability of a financial state of the firms (that has been characterized through discriminant model) for five years, see Table 6 . Nevertheless, Russian hybrid military aggression (that was followed by annexation of a part of national territory and huge economic blockade) significantly slowed down pace of development of such economic sector; it caused market reorientation and a rise of weight of sector in national export and its transformation into the locomotive of GDP growing. In particular, correlation between export of products from oil-bearing crops and total GDP rose in post-revolutionary period and reached 0,89 at all 5-year interval (see Table 4). It says about restructuring of national GDP in post-revolutionary period towards agriculture production (the break-up of technological communications and loss of the northern market for the products of other economic sectors were two main reasons for such process).Sunflower oil production as one of engines of the national economy feels rather a negative influence of state support (see Table 5).

We have offered some technique to determine the most influential financial coefficient through the factor analysis of discriminant model and assessment of deviations of its result. The analysis has defined that in $75 \%$ of cases the coefficient of financial independence, or autonomy $\left(\mathrm{k}_{3}\right)$ had the most power. Besides, the importance of this coefficient has increased after the Revolution of Dignity (see Table 8). This means that the set of instruments that influence a corporate financial state, had significantly narrowed in the post-revolutionary crisis of the financial market. Obviously, a set of such financial instruments will rise with further Ukraine integration into the European economic environment.

\section{REFERENCES}

Andriychuk, V. G. (2013). Ekonomika pidpryemstv agropromyslovogo kompleksu [Economic of the Agricultural Enterprises]. Kyiv: KNEU.

Barghash, R. M., Othman, A.Z., \& Youssef, R. A. (2014). Economic Study of Main Oilseeds Production and Consumption Indicators in Egypt. Life Science Journal, 10(11). Retrieved from: http://www.lifesciencesite.com/lsj/life1110/152 26834blife111014 984 993.pdf (Accessed 24 December 2016).

Boland, M., \& O’Brien, D. (2002). Economic Issues with Sunflowers. Agricultural Marketing Resource Center, Kansas State University, USA, 60(8), 1561-1566. Retrieved http://www.agmrc.org/media/cms/ksueconsunflowers_932B717632F04.pdf (Accessed 24 December 2016).

Business Opportunities for Biobased Economy: Ukraine and The Netherlands (2013). Pro Marketing Ukraine. Retrieved from: $\quad$ http://www.agroberichtenbuitenland.nl/kiev/wp-content/uploads/sites/4/2014/11/BBE-study2013 Ukraine.pdf (Accessed 24 December 2016).

Fedoryaka V. P., Bakhtshivanzhy L. O., \& Potchkolina S. V. (2013). Efektyvnist vyrobnitstva i realizatsii sonyashnykiv Ukraini [Effectiveness of Sunflower Production and Sales in Ukraine]. Bulletin of Social and Economic Researches, 41(2), 139-144.

Fine, F., Lucas, J. L., Chardigny, J. M., Redlingshöfer, B., \& Renard, M. (2015). Food losses and waste in the French oilcrops sector. Oilseeds and Fats, Crops and Lipids, 22(3). Retrieved from: http://www.ocljournal.org/articles/ocl/pdf/2015/03/ocl150012-s.pdf (Accessed 24 December 2016).

Helgeson, D. L., \& Schaffner, L. W. (1983). Economics of on-farm processing of sunflower oil. Journal of the American Oil Chemists' Society, 60(8), 1561-1566. Retrieved from: http://library.ndsu.edu/tools/dspace/load/?file=/repository $/$ bitstream $/$ handle/10365/4673/farm_39_04_0 1.pdf?sequence $=1$ (Accessed 24 December 2016). 
Infografic Reference Book: Agrobusiness of Ukraine-2015 (2015). OJSC «Ukrainian Universal Exchange». Kyiv: BakerTilly. Retrieved from: http://uub.com.ua/wp-content/uploads/2015/09/Ukrainian-Agribusiness2015.pdf (Accessed 24 December 2016).

Kucherenko, S. Y. (2015). Organizatsionno-ekonomichni zasady efektyvnogo vyrobnitstva sonyashniku v Ukraini [Organization and Economic Bases of Sunflower Production in Ukraine]. Economic Bulletin of the PereyaslavKhmelnitsky State University named after Hryhory Skovoroda, 24(1), 45-48.

Mihalovic, M. (2016). Performance Comparison of Multiple Discriminant Analysis and Logit Models in Bankruptcy Prediction. Economics \& Sociology, 9(4), 101-118.

Politika schodo investuvannya u silske gospodarstvo [Politics of Investment Into Agriculture] (2015). Strategiya sektornoi konkurentospromozhnosti dlya Ukrainy - phaza III [Sector Competitiveness Strategy for Ukraine - Phase III]. Kyiv: OECD. Retrieved from:

http://www.oecd.org/globalrelations/Agricultural Investment Policies Ukraine UKR.pdf (Accessed 24 December 2016).

Producer and Consumer Support Estimates Database (2016). The Organization for Economic Cooperation and Development; OECD. $\quad$ Retrieved from: $\underline{\text { https://www.oecd.org/tad/agricultural- }}$ policies/producerandconsumersupportestimatesdatabase.htm (Accessed 24 December, 2016).

Samaeva, J. (2016). Prodat lyuboy tsenoy [To Sell at Any Cost]. Zerkalo Nedeli. Ukraine, 31. Retrieved from: http://gazeta.zn.ua/ariculture/prodat-lyuboy-cenoy-_.html (Accessed 24 December 2016).

Situation of human rights in the Autonomous Republic of Crimea and the city of Sevastopol (Ukraine) (2016). UN Resolution 15.12.2016. Retrieved from: http://www.un.org/ga/search/view_doc.asp?symbol=A/C.3/71/L.26 (Accessed 24 December 2016).

State Statistics Service of Ukraine (2016). SSSU. Retrieved from: http://www.ukrstat.gov.ua (Accessed 24 December 2016).

Verkhovod, I., \& Petrenko, V. (2014). Analysis of dependence in Ukrainian enterprises' economic indicators from measure of their innovation activism. Economics \& Sociology, 7(3), 76-89. 